\title{
ANATOMICAL AND ROENTGENOLOGICAL INVESTIGATION OF THE MAXILLARY SINUS
}

Part III. On the Bony Floor of the Maxillary Antrum observed from Intraoral Roentgenography.

By T. YANO

From the Department of Oto-Rhino-Laryngology, Tokyo Medical and Dental University. (Director: Pref. S. Horiguchi).

In order to study the condition of maxillary sinus in relation to the etiology of chronic paranasal sinusitis, the author carried out an intraoral roentgenographic study of the bony floor of the maxillary sinus of 298 cases with chronic sinusitis, and 302 normal cases, and a histological study on 32 materials of facial wall. Result are as follow.

Bony cortex of maxillary sinus develops until 18 19 year of age in normal group, the comoletion is retanded, however, in afficted group and the development toward antral floor is arrested at the age of 10 11, accompassied by the hypertrophy of the bony floor of the maxillary antrum.

There is no significant difference in the condition of the bony floor of the maxillary antrum between young adult (20 35year) and aged (36 59year).

The relationship between the chronic paranasal sinusitis and the maldevelopment of sinus wasseen in a little less than $30 \%$, which is signicantly defferent from normal control group.

Histopathological study showed inflammatory change of facial wall in 4 cases (12.5\%), bony change due to reconstruction in 30 cases $(93.8 \%)$.

Bone absorption appered to be common in those cases with well developed maxillay sinus, and osteoblastic activity was marked in cases with maldeveloped maxillary sinus.

\section{上顎洞の解剖学的並に「レ」線学的研究}

\section{第3 編 口内法「レ」線像より観察せる上額洞底骨層について}

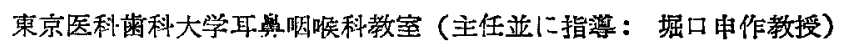

矢野武

\begin{tabular}{|c|c|c|c|c|}
\hline \multirow[b]{2}{*}{ 第 1 章 } & \multirow{2}{*}{ 目次 } & \multicolumn{2}{|c|}{ 第4 章＼cjkstart総括並に拷按 } & \multirow[b]{3}{*}{$=$} \\
\hline & & 第 5 章 䊅 & 語 & \\
\hline 第 2 音 & 観察材料並に方法 & & 第 1 章 緒 & \\
\hline 筑章 & 観察成續 & 慢性副鼻洞 & つ成因本態に関 & ててなほ不明なる現在。 \\
\hline 第 1 项 & 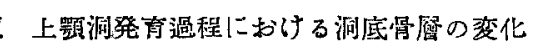 & 各方面より種 & D研究がなされ & いる・その一睘として \\
\hline 第 2 項 & 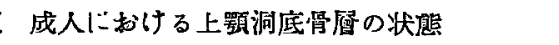 & 上顠洞底骨層 & 开究は，鼻科及 & 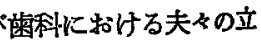 \\
\hline 第 3 項 & 画性上颚洞炎における洞底骨櫫の状態 & 場より，また & 共同で解剖学 & , 病理学的, 2 楾学的 \\
\hline 第 4 項 & $\begin{array}{l}\text { 上䫟洞骨壁の状態と Pneumatisation との } \\
\text { 関保 }\end{array}$ & $\begin{array}{l}\text { に多数の業林 } \\
\text { 万根又はそ。 }\end{array}$ & 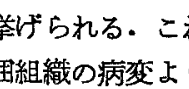 & 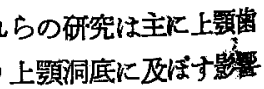 \\
\hline
\end{tabular}


を䛨紐们つている。

堀口教授 ${ }^{37)}$ は歯性上顎洞炎に関する研究で，その特 徽あるい忙の発生に関する 推理の 妥当性を基碟とし て，潜在性の米性慢性副鼻洞炎を発見し，慢性副鼻洞炎 といら不可解な疾患に対しくさびを折込もらというにあ ると述べている如く，少くともある種の副鼻洞炎の場 合, 解剖学的に上㖽歯牙の位置的関係を無視することは できない.

そこで著者は第 1 編の研究を基礎とした口内法による 洞底レ線写真で，副番洞正常者及び慢性副鼻洞炎，歯性 上顠洞炎の患者を撮影し，洞底画根間骨層の距離を湘定 すると同時に洞底骨壁の器質的な変化を判読できる洞底

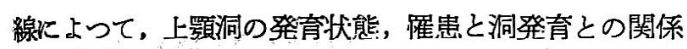
を年令的炕検討するとつもに，病理組織学的所見をも検 索した。この方面よりの研究は慢性副嶴洞炎による上顎 洞骨壁の状態並に成因に関する本態究明に対し何等かの 示唆を与えるものと信じ，こつに大要を報告して御批判 を仰ぎたい。

\section{第2 章 観察材料並に方法}

観察材料と乙て東京医科歯利大学耳鼻咽喉科外来を訪 れた患者より，既往歴及び自覚症状なく，鼻鏡検查で副 奥洞正常者 302 名 (386 側), 鼻鏡検查, 顔面レ線写真,

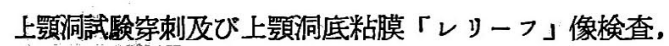

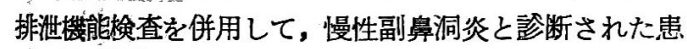
者 298 名 (457 側)，齿性上顎洞炎の患者 42 名 (42 側) に対し, 口内法により上顎洞底骨層を撮影して「レ」線 学的に観察試みた。

方法饰】編に特ける実験的矿究で観察された如く， 上䫑洞底の形態々各上顎米牙根との解剖学的関係を正確 に観察するため，レ線撮影に際して X 線主軸方向は咬 合平面に対し約 $30^{\circ}$ とし, Cieszynskie の法則により㐪 科用フイルム面と歯軸とのなす角度の 2 等分線炕直角方 向に一致するよう，幾分修正して放射せしめた。

撮影条件は電圧 $60 \mathrm{KVP}$, 電流 $20 \mathrm{~mA}$, 焦点皮虞距離 $5 \mathrm{~cm}$, 時間 1.5 秒とした.フィルムは普通市販されてい る $3 \times 4 \mathrm{~cm}$ の歯利用フイルムを用いた。

病理組織学的検索は慢性副鼻洞炎患者の手術時に採取 した閶面骨壁 32 例について行つた・標本は脱灰後, パ ラフイン包㻎，へマトキシリン，エオジン重染色を行つ で観察した.

\section{第3章、観 察成續}

1 この方法により撮影された上顎洞底骨層につき距離的 並に洞底線の变化によって次の如き分類を行つた。

\section{1. 洞底曾稂間骨層の分類}

洞底㐘根間骨層の厚さは，顔面し湶写真と共に観察す ると上顎洞容樍に密接な相関に係がみられる・この厚さ は洞底線と上顎蒾牙煩側根端間の距離によつて現わされ らることを第 1 編によつて検行し，これを洞底霜根間の 距離として測定し，次の如く3群に分けた。

1) 洞底曾根接群：レ線像上で大目雪の煩側両根が洞 底線と僅かに交叉するか接している場合で，解剖学的に 洞底歯根間の骨壁が非常に薄く，洞底と米根がほとんど 接していると考えられる例，勿論上頢洞発育の良好な正 例である.

2) 洞底歯牙接近群：大田歯煩側根と洞底線との間に 1〜4mm の骨層が存在し，雬根より洞底に 種々の影響 が考えられるもの. 顔面レ線写真に特いても上顎洞の発 育は良好である。

3）洞底歯牙遠距離群：洞底歯根間の距離が明らかに 離れており, 測定値も $4 \mathrm{~mm}$ 以上の症例で, 洞発育も や」不良なるのである。

\section{2. 洞底線の分類}

上顎洞発育の際及び羅患状態により，洞底部骨皮質の 变化に徉つて洞底線にも種たの影像が観察され，これを 次の 4 型に分類した（第 1 図）.

1）I型；上顎洞底において明瞭な細線を画くもの.

2）【型；太く明瞭に現われている洞底線を示すも の.

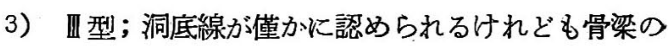
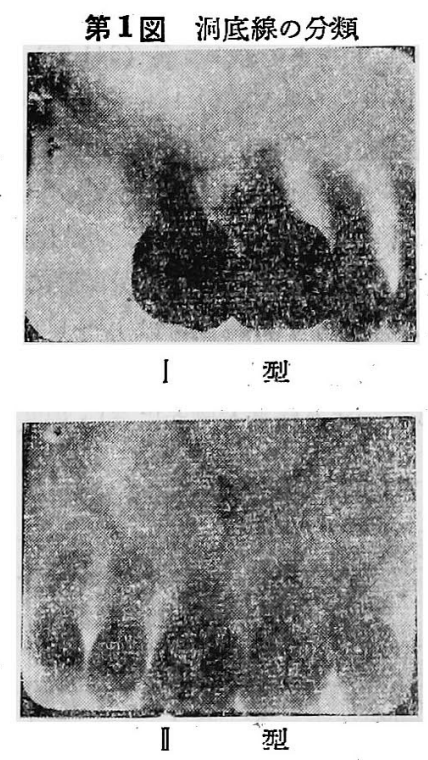

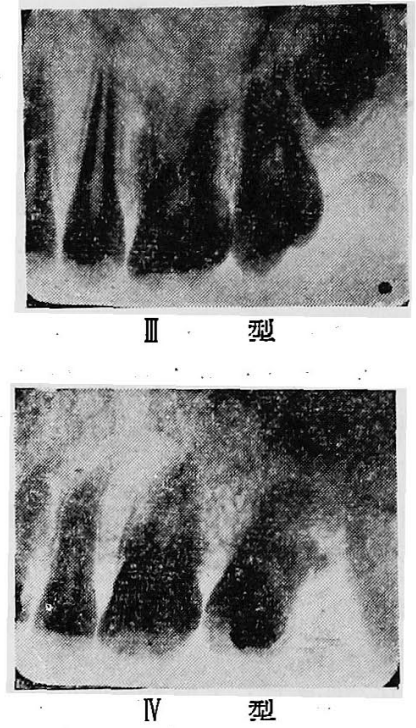

䎦理と洞底線との境界が不明瞭で判定しにくいもの.

4） IV 型; 洞底米根間骨層が厚く，洞底線が現れない もの． 即ち IV 型は洞底歯根間距離の分類に関連して，顔 面レ線像 (前後径) に招いても，洞発育抑制が強い症例 で, 霜牙の影響をうけない。

以上の分類で洞底荬根間骨層の距離的関係並に骨皮質 の状態を統計的に観察を行つた。

第 1 項 上顎洞発育過程における洞底骨绝の変化 年令的に9方迄の症例については乳㐘残存のためレ線 像上で洞底線の 観察が困難で，㓋察材料を第 1 表の如 く，10才から19才までの198名 (341 側) とし, 10〜 11 才, 12〜13才, 14〜15才, 16〜17才, 18〜19才の 5 群に分け，各群を前述の分類に従つて正常群と罹患群と を観察し，第 2 表，第 3 表に示し比較検討した。

正常群に打ける洞底菌根間骨層は洞底蒾牙接近群と接 群が 147 例で 92.5\%を占め，大部分洞底に菌根が接近 していることを示す. 年令的には10１1才にまだ乳畨 残存例があるが，洞底歯根接群と洞底歯牙接近群之の関 係は 12〜13 才頃より後者が僅かに多い程度で永久歯萠

第 1 表 被検者年令分布

\begin{tabular}{|c|c|c|c|c|c|c|}
\hline 590 44 & $10 \sim 11$ & $12-13$ & $14 \sim 15^{\circ}$ & $16-17$ & $18 \sim 19$. & 計 \\
\hline \multirow{2}{*}{ 正常群 } & 18 & 17 & 18 & 19 & 19 & 9. \\
\hline & 33 & 30 & 32 & 32. & 32 & 159 \\
\hline \multirow[t]{2}{*}{ 据焦群 } & 15 & 23 & 27 & 22 & 20 & 107 \\
\hline & 27 & 39 & 45 & 45 & 36. & 182 \\
\hline
\end{tabular}

第 2 表 上顠洞発育過程によ゙ける河底骨膡の 変化（正常群）

\begin{tabular}{|c|c|c|c|c|c|c|c|}
\hline \multicolumn{2}{|c|}{ 洞壁 } & $10 \sim 11$ & $12 \sim 13$ & $14 \sim 15$ & $16=17$ & $18 \sim 19$ & 敦 \\
\hline \multirow{3}{*}{ 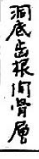 } & 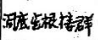 & 10 & 13. & 14 & 15 & 13 & \multirow{2}{*}{$\begin{array}{l}147 \\
(225 \%)\end{array}$} \\
\hline & 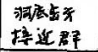 & 18 & 16 & 16 & 15 & 15 & \\
\hline & 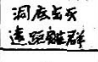 & (5) & 1 & 2 & 1 & 4 & $\begin{array}{l}12 \\
(25 \%)\end{array}$ \\
\hline \multirow{2}{*}{ 洞 } & I & 8 & 14 & 16 & 18 & 18 & $\begin{array}{c}74 \\
\left(4 s^{2} s_{i}\right) \\
\end{array}$ \\
\hline & II & 2 & 4 & 6 & 8 & 11 & $\begin{array}{c}3.1 \\
(17.5 \%)\end{array}$ \\
\hline \multirow[t]{2}{*}{ 缘 } & III & 18 & 12 & 10 & 6 & 2 & $(36,2 \%)$ \\
\hline & $\mathbb{N}$ & (5) & 0 & 0 & 0 & 1 & $\begin{array}{c}6 \\
\text { (1.28\%) }\end{array}$ \\
\hline
\end{tabular}

第 3 表，上顎润発育過程に゙おける洞底骨噟の 变化 (䍜患群)

\begin{tabular}{|c|c|c|c|c|c|c|c|}
\hline \multicolumn{2}{|c|}{ 洞底 年令 } & $10 \sim 11$ & $12 \sim 13$ & $14 \sim 15$ & $16 \sim 17$ & $18 \sim 19$ & 計 \\
\hline \multirow{3}{*}{ 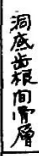 } & 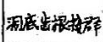 & 4 & 8 & 17 & 12 & 4 & \multirow{2}{*}{$\begin{array}{l}125 \\
(61.7 \%)\end{array}$} \\
\hline & 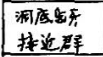 & 16 & 12 & 19 & 21 & 12 . & \\
\hline & 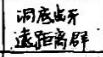 & 7 & 9 & 9 & 12 & 20 & $\begin{array}{l}57 \\
(31.3 \%)\end{array}$ \\
\hline \multirow{4}{*}{$\begin{array}{l}\text { 洞 } \\
\text { 底 } \\
\text { 缐 }\end{array}$} & I & 5 & 5 & 7 & 8 & 3 & $\begin{array}{c}28 \\
(15,4 \%)\end{array}$ \\
\hline & II & 0 & 3 & 8 & 1.2 & 17 & $\begin{array}{l}40 \\
(22.0 \%)\end{array}$ \\
\hline & III & 19 & 17 & 25 & 16 & 4 & $\begin{array}{c}81 \\
(445 \%)\end{array}$ \\
\hline & $\bar{D}$ & (3) & 4 & 5 & 9 & 12 & $\begin{array}{c}3.3 \\
(887 \%)\end{array}$ \\
\hline
\end{tabular}

出に際して変化することはない、洞底線についてI型は 11〜12才頃に急激に増加し，13 才頃より増加率が场 やかである (第 2 図). II 型は年令増加に比例し 19才頃 には約 35\% となつている. (第 3 図). III型はI 型と反対 に減少し，18〜19才には1\%以下となつてい第4 図)、N 型は乳迷残存のため洞底線がレ線上に現れない もの 5 例を除けば18〜19才の群に 1 例存在するのみて ある・

㢈患群に打いて洞底歯根間骨層は洞底歯牙接近群が 80 例で最も多く，次に洞底歯牙遠距離群で 57 例, 洞底 函根接群吕 45 例之なつている。年令的汒 15 才汽怆者 の間にあまり变化がみられないが，16〜17才頃より洞 底歯牙遠距離群が漸次多くなつているのか㴤目される。

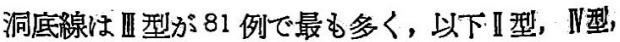
I 型となっている. 年令的には I 型に変化なく (第2 図)，II 型は年令増加と共に 潮次多くなつている (第3 図)、【型は次第に減少している（第 4 図)、N型忤命 と共に増加し，16〜17 才頃より増加率が高くなゔてい 
る.

以上正常群と羅患群とを比較すると，洞底荬根間骨層 は正常群の洞底根接群と洞底蒾牙接近群との割合が注 シ同数であるのに反し，䍜患群では後者が前者の約 2 倍 となつている. 李た洞底㐘牙遠距離群が $31.3 \%$ を占め ているのが特徽である. 年令別分布は正常群で洞底婳根
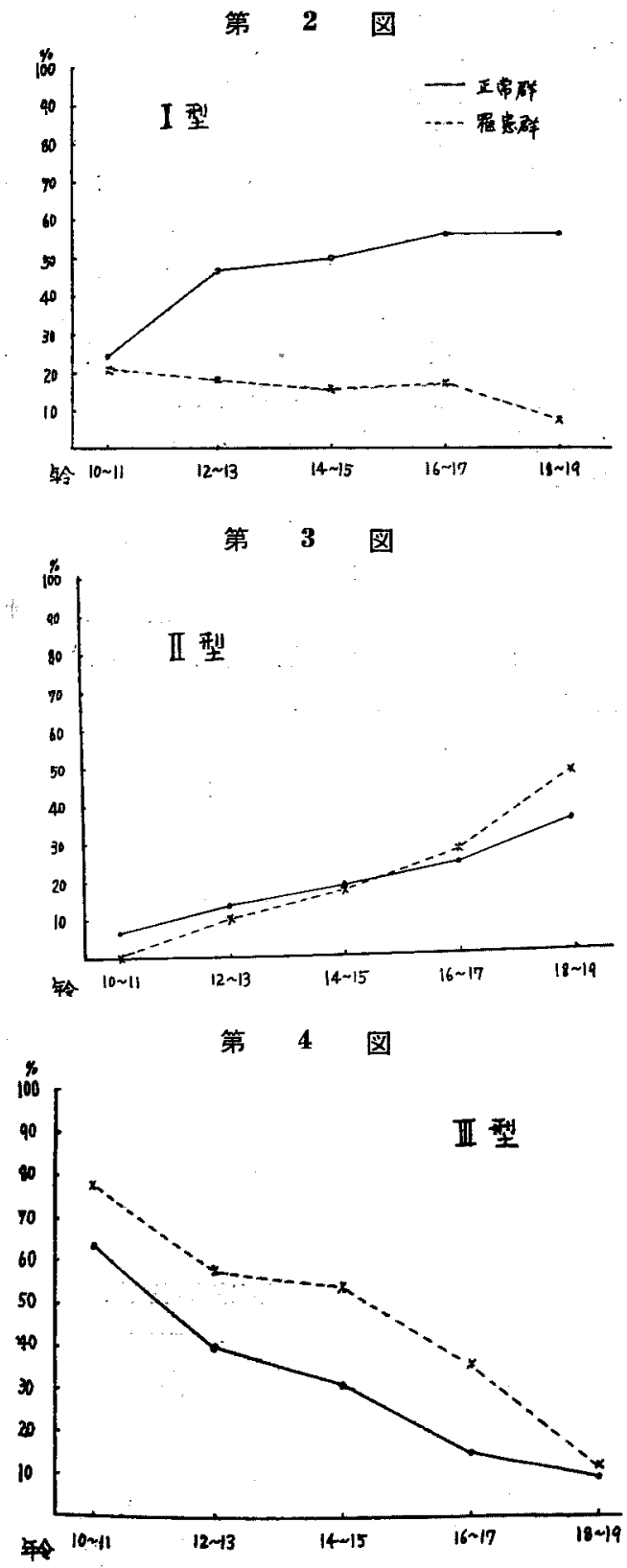

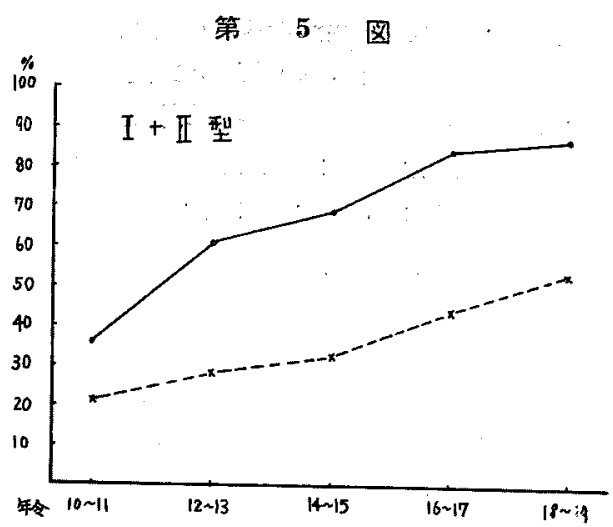

接激が僅が堌加し，洞底㐘牙接近群が蔵少しているの に反し，西患群は 14〜17 才頃に 洞底雬牙接近群が多小 けれども，18〜19 䪱になると洞底霜可遠距離群が非 常に増加して最も多くなる。

洞底線は正常群に括いてI翟が最も多く，46.5\%を占

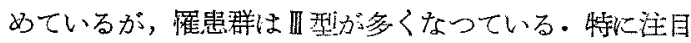
される点は洞底霜根間骨簤の遠距離群の場合之同樣に $N$ 型で，正常群は8 例認められるのみであるが，惟患洋代 33 例孔存在し，年令之共偪加の傾问を示している。 年令別分布を各型について総合してみると第 2 図〜第 5 図に示した如く，I型の 10〜11 才頃は正常群，罹患 群共䄪 $20 \%$ と同様の状態であるが，前者は16〜17才文 で渒次増加しているのに反し，後者は18〜19才までに

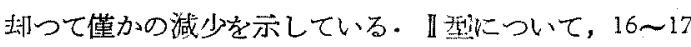
才までは両者共同㥞に堌加しているが，その後㢈患郡の 増加率が高くなつて 18〜19才頃には50\%近くなつてい る・四型怔常群，䍜患碚共，同様な曲線をるつて年令 と共に減少し，18〜19 于になると両者に差がみられな くなつている。

第 2 項 成人に打ける上顎洞底骨層の状態

観察材料の対象年令は一応上疑洞骨壁が完成されてい る20才以上の正常者 211 名 (277 側)，慢性副鼻洞炎上 猃断された患者 191 名（275側）を観察した：その年命 分布は第４表に示卞如くである。

第4 表 被検省年命分布

\begin{tabular}{|c|c|c|c|c|c|}
\hline 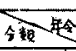 & $20 \div 29$ & $30 \sim 39$ & $40 \sim 49$ & $50 \sim 59$ & 部 \\
\hline \multirow{2}{*}{ 正常群 } & 105 & 54 & 33 & 19 & 211 \\
\hline & 142 & 71 & 39 & 25. & 277 \\
\hline \multirow{2}{*}{ 准宫群 } & 90 & 69 & 21 & 13 & 191 \\
\hline & 132 & 97 & 28 & 18 & 275 \\
\hline
\end{tabular}


この被検者に 対し年令を 20〜35才の青年期と 36〜59 才までの壮年斯派分けた． 60 才以上の慢性副奥洞炎患 者が少数のため，老年期は統計から除外した．その年令

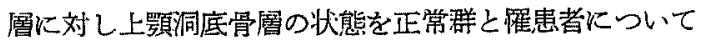
第 5 表，第 6 表に示し，耐者を比較検討した。

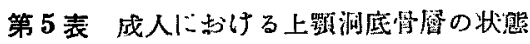
(正常粼)

\begin{tabular}{|c|c|c|c|c|c|c|c|c|}
\hline \multirow{2}{*}{ 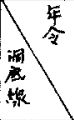 } & \multicolumn{2}{|c|}{ 青 } & 年 & 槙 & \multicolumn{2}{|c|}{ 牞年 } & \multicolumn{2}{|c|}{ 期 } \\
\hline & 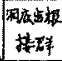 & 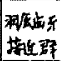 & 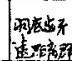 & 計 & 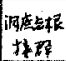 & 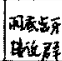 & 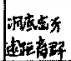 & 計 \\
\hline$I$ & 49 & 32 & 0 & $\begin{array}{c}81 \\
(4 . \%)\end{array}$ & 14 & 21 & 0 & $\begin{array}{c}35 \\
(* 7 \%)\end{array}$ \\
\hline II & 17 & $4 !$ & 14 & $\begin{array}{c}72 \\
(32 \div \%)\end{array}$ & 2 & 23 & 9 & $\begin{array}{c}34 \\
(4.5 \%)\end{array}$ \\
\hline III & 6 & 16 & 8 & $\begin{array}{c}30 \\
(156 \%)\end{array}$ & 1 & 8 & 2 & 11 \\
\hline $\mathbb{N}$ & 0 & 0 & 10 & $\begin{array}{c}10 \\
(5.2 \%)\end{array}$ & 0 & 0 & 4 & $\begin{array}{c}4 \\
48 \%)\end{array}$ \\
\hline 計 & & 1 & $\begin{array}{l}32 \\
(16.78\end{array}$ & 193 & & 9 & $\begin{array}{c}15 \\
179 \%\end{array}$ & 84 \\
\hline
\end{tabular}

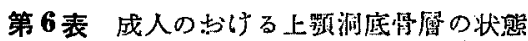

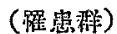

\begin{tabular}{|c|c|c|c|c|c|c|c|c|}
\hline \multirow{2}{*}{$\begin{array}{l}\text { 年 } \\
\text { 的 } \\
\text { 底 } \\
\text { 战 }\end{array}$} & \multicolumn{2}{|c|}{ 着 } & \multicolumn{2}{|c|}{ 年期 } & \multicolumn{4}{|c|}{ 版 年 期 } \\
\hline & 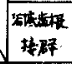 & 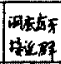 & 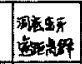 & 計 & 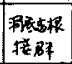 & 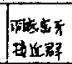 & 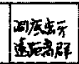 & 計 \\
\hline I & 14 & 3 & 0 & $\begin{array}{c}17 \\
(79 \%) \\
\end{array}$ & 5 & 2 & 0 & $\begin{array}{c}7 \\
(22.8 z) \\
\end{array}$ \\
\hline II & 19 & 60 & 18 & $\begin{array}{c}97 \\
(45.3 \%)\end{array}$ & 8 & 14 & 6 & $\begin{array}{c}28 \\
(509 \%\end{array}$ \\
\hline III & 2 & 24 & 15 & $\begin{array}{c}41 \\
(192 \%)\end{array}$ & 0 & 4 & 4 & $\begin{array}{c}8 \\
(\sqrt{4} .5 \%)\end{array}$ \\
\hline $\bar{N}$ & 0 & 0 & 59 & $\begin{array}{c}57 \\
(276 \%)\end{array}$ & 0 & 0 & 18 & $\begin{array}{c}18 \\
229.5 \%)\end{array}$ \\
\hline 㝄 & $\begin{array}{l}12 \\
157\end{array}$ & $2 \%$ & $\begin{array}{l}.92 \\
(430 \%)\end{array}$ & $2 / 4$ & & 33 & $\begin{array}{c}26 \\
(* 3.9 \%) \\
\end{array}$ & 61 \\
\hline
\end{tabular}

正常群の洞底歯根間骨凰に関して洞底歯根接群ならび 洞底雨牙接近群の耐者と洞底幽牙遠距離群之の関係は 猆年期，壮年期洪百分率に豦がみられないままた接近群 の耐者を钼察すると，禹者の比は青年期にはとえど空が ないのに反し，壮年其期は洞底歯牙接近群が洞底歯根援群 の 2 倍以上の症例数を示している. 洞底線については， 青年期，壮年期とす各型の百分率が同傾问を示してお

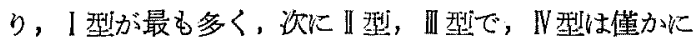
$5 \%$ と洞底来根間骨翼が厚くなつている症例は非常に少 くなつている・青年期，壮年期の雨著間に东られる櫵か な変化は後者に』型が多く，【刑が少くなつている点の みである。
罹患群における洞底歯根間骨層の距離は，青年期，壮 年期とも洞底歯牙遠距離群が最も多く，約 $40 \%$ を占め， 洞底歯牙接近群もとれに近い率を示し，洞底雪根接群が 最も少小。

この場合も年令的に両者に差がなく同様な傾向を示し ている. 洞底線についても，青年期の II 型が $45 \%$ ，壮 年期か 50\% と約半数で最む多く，次にN型，四型，最 む少いのはI型で約 10\%である。

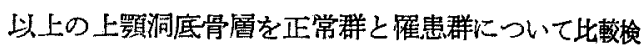

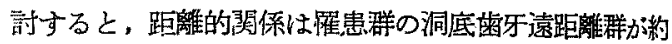
3割も多くなつていることである・洞底線の状態につ ては, 正常群に I 型, II 型が多いのに比し, 䍜患群はI 型が約 1 割程度上非常に少くなつている・四型はほ5同 交であるが，V 型は正常群が5\%であるに反し，䍜患群 は約 $30 \%$ 弱と多くなつている・即ち N 型の如く， レ線 像上に洞底線が現れていない上顎洞発奋抑制の症例が慢 性副鼻洞炎群の中に的 3 割む含をれていることは注目に 値する.

\section{第 3 項 歯性上顎洞炎に括ける洞底画根 間骨篔の状態}

函性上䪽洞炎の観察材料を年令的化性別，側別に分け 第 7表に示した・䍜患者の性別は同数であり，側別む任 ぶ同数である・年命別分布状態は20〜39才の間に約 80 \%を占めている。

米性上顎洞炎の上顎洞底骨凰の状態を第8 表に示し た.

第 7 表 性别 僛別分布

\begin{tabular}{|c|c|c|c|c|c|c|}
\hline 啮输 & $20-27$ & $30-39$ & $40 \sim 49$ & 50.57 & $60 \sim 69$ & $z+$ \\
\hline 罗 & 5 & 9 & 1 & 3 & 3 & 21 \\
\hline 4 & 5 & 11 & 3 & 2 & 0 & 21 \\
\hline \multicolumn{7}{|c|}{ 年全分布 } \\
\hline 14 & 20229 & $30 \sim 39$ & $40-49$ & $50 \sim 59$ & $60 \sim 69$ & 部 \\
\hline t & 6 & 8 & 2 & 1 & 3 & 20 \\
\hline t & 4 & 12 & 2 & 4 & 0 & 22 \\
\hline
\end{tabular}

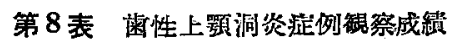

\begin{tabular}{|c|c|c|c|c|}
\hline 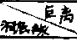 & 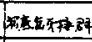 & 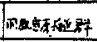 & 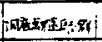 & it \\
\hline$I$ & 10 & 1 & 0 & $11(26 \%)$ \\
\hline II & 7 & 5 & 0 & $12(2.6 \%)$ \\
\hline III & 13 & 6 & 0 & $19(452)$ \\
\hline$\pi$ & 0 & 0 & 0 & $0(0 \%)$ \\
\hline 竍 & 30 & 12 & 0 & 42 \\
\hline
\end{tabular}


表の如く洞底菌根接群が最も多く 30 例 (71.4\%)，洞

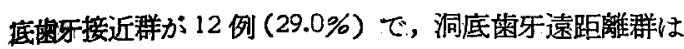
1 例むない. 洞底線については型が多く，19 例認めら れ，I 型，I型とも注之同数である－故に歯性上顎洞炎 は往来の各研究者が報告している如く，全例洞底雪根間 が接近しているけれども，その中に洞底㐘牙接近群が約

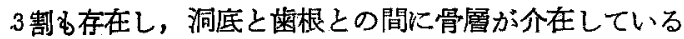
症例が観察されることは慢性副鼻洞炎に执いて子洞底莱 牙接近群に整性因子を推察しうる。

\section{第4 項 上㖽洞骨壁の状態と Pneumatisation との関係}

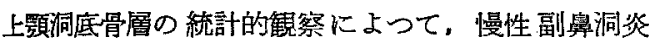
患者の約 $30 \%$ 弱に（レ線像上に洞底線を現さない） N 型の洞底曾牙遠距離群が 存在することが明らかとなつ た.この症例に対し上顎洞根治手術を施行した所，全例 Mikroböhle (洞容積 7cc 以下)であり，著者は洞底歯根 間骨層の距離的联係を上顎洞発育状態判定の一基準とす ることができ洞底蒛牙遠距離群中の IV 型を洞発育不良， 洞底茵牙接近群及び洞底画根接群の両者を洞発育良好, その中間に属するものを洞発育中等度と分類し，前項の 慢性副鼻洞炎観察例上り無作為に32 例を手術した。手 術時ににできるだけ上颔洞底に近い、顔面骨壁を採取し， 骨組織所見の最も重要な变化である炎症の有無，骨構造 の变化，即ち Umbau（改構）に站して検索し，第 9 表 の如くに示した。

Umbau については，骨级収並に骨新生の生理的变化

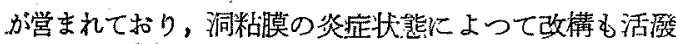
となり，平衡的䓟係がみだれてくる・この变化の高度な ものを州，中等度のものH，整度なものを十，变化のみ られないものを一，また变化の明らかでないものを士で 表わした。

第9表上り炎症交び Umbau について観繁すると， 先つ骨組織の 炎症状態は 32 例中 4 例で，洞発育良好例 水3 例，中等度例飞 1 例あるか，不良例にはみられなか つた４例中炎症中等度のものは1例のみであつた。 た炎症性骨病変を示した症例の粘脱病変は，浸潤浮罝型 及び唚潤型で高度の変化が存在するものに諰められた。 Umbau は 32 例中 30 例儿陽性 (十) で，他の不明瞭な .2例も骨採取不十分なため判定ができなかうたものであ る.

次に洞発育に対する骨新生之骨吸収との関係について 述べると，洞発育良好例は骨新生中等度のもの1 例と， 骨新生のみを現するの 2 例で，堌殖像が現れているもの

\section{第 9 表}

\begin{tabular}{|c|c|c|c|c|c|c|c|c|}
\hline 閆难 & 有庭例 & 年令 & 性 & 粘膜所見 & 炎症 & Umbar & 骨新生 & 骨吸收 \\
\hline & 7 & 16 & $q$ & $\operatorname{Tht}^{2+(N)}$ & + & + & $=$ & - \\
\hline & 2 & 26 & $\frac{1}{8}$ & 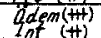 & $H$ & $t$ & - & 4 \\
\hline & 3 & 23 & $q$ & defen(in) & - & + & - & + \\
\hline & 4 & 77 & a & $\overrightarrow{0}^{\prime} \mathrm{em}(++1)$ & - & + & - & $\div$ \\
\hline & 5 & 16 & f & $\operatorname{lnf}_{b}(+)$ & - & + & + & + \\
\hline 艮 & 6 & 23 & iq & $a^{8 d e m}(++)$ & - & + & + & + \\
\hline & 7 & 26 & 1 & tem & $=$ & + & + & $\div$ \\
\hline & 8 & 23 & 8 & $\ln ^{2}(\mathrm{f}+1)$ & - & + & + & $t$ \\
\hline & 9 & 25 & o & 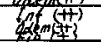 & $\overline{-}$ & + & + & + \\
\hline & 10 & 22 & $\delta$ & Iif $(++)$ & $=$ & + & $H$ & + \\
\hline & 11 & 18 & $\hat{\delta}$ & $\ln f(+H)$ & + & + & + & - \\
\hline & 72 & 22 & 8 & ddem(t) & - & + & + & - \\
\hline & 13 & 23 & 8 & $\ln f(+1+)$ & - & \pm & - & \pm \\
\hline & 14 & 25 & 9 & & - & + & + & + \\
\hline & 15 & 24 & 9 & $\ddot{0} \operatorname{dem}(H)$ & - & $t$ & + & $\div$ \\
\hline & 16 & 27 & 9 & bidef (iti) & - & + & \pm & + \\
\hline 等 & 17 & 30 & 8 & dem & - & + & + & 4 \\
\hline 度 & 18 & 25 & 高 & thf(t) & + & + & + & $\div$ \\
\hline & 19 & 26 & 8 & $\ln f(t)$ & - & + & \pm & $\div$ \\
\hline & 20 & 25 & 8 & $F_{i b(H)}$ & $=$ & + & $+t$ & $=$ \\
\hline & 21 & 51 & 8 & $\ddot{D} d \operatorname{lem}(t+1)$ & - & + & + & + \\
\hline & 22 & 17 & 8 & Fib (\$) & - & $t$ & + & - \\
\hline & 23 & 23 & $\begin{array}{l}1 \\
0 \\
\end{array}$ & $f i b(+)$ & - & + & + & + \\
\hline & 24 & 27 & $\frac{1}{8}$ & $F_{i b}(H)$ & - & + & + & + \\
\hline 不 & 25 & 23 & $\hat{s}$ & Eib (t+) & - & + & $\#$ & + \\
\hline & 26 & 20 & 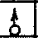 & Fib $(\mathrm{HH})$ & $=$ & + & + & + \\
\hline & 27 & 20 & $\begin{array}{l}1 \\
0\end{array}$ & Znf $3+1+1$ & $=$ & $t$ & \# & + \\
\hline 良 & 28 & 16 & q & 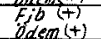 & - & + & H & - \\
\hline & 29 & 20 & 8 & $F i b(+)$ & - & + & + & $=$ \\
\hline & 30 & 21 & q9 & $F_{i b}(+)$ & - & \pm & \pm & - \\
\hline & 31 & 27 & 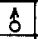 & $\operatorname{Inf}(t)$ & - & \pm & $\mp$ & + \\
\hline & 32 & 27 & $\frac{1}{b}$ & & $=$ & + & $H$ & - \\
\hline
\end{tabular}

3 例であるのに反し，骨吸収像が強く現れているさの5 例（骨级収高度のわの1例を含む）上，幾分吸収性变化 の方が強く認められ，また再者の状態が同程度行放れて いるものも5例存在した・不良例に和いては，11例中 6

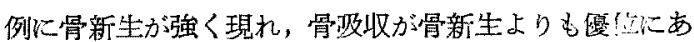
るものは1例もみられなからた，洞発育中等度例では 8 例中骨吸收が強いもの，骨新生が強いものが华心1例ら つあるが，大体に扒いて骨組織内の Umbauは平衡閣。 係を保つている。

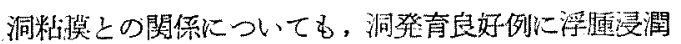
型が多く，不良例には線維型のものが多い順向を示して いる.

\section{第4 章 総括並に考按}

上顎洞夶育に関しては古くから解剖学的, 上線学的に

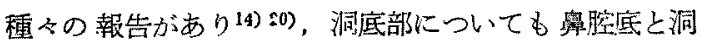


底との関倸によつて禹槽窩存否を年令的に観察し，洞下 方えの発育を報告している. Stern 7 は10〜15 䪱よ り桼槽简が見れ，20才まで僅が増加率を示すが，そ れ以後変他がない.Sedwick ${ }^{5}$ ) 頭蓋の 登育と同時に 洞の上下径が 20 寸まで発育すると述べている・著者の 観察によると乳速残存例では洞底線が 不明膫で永久霜 ネ胞上に梁接しているため，正常群と罹患群との間に洞 底逐根間骨層の距踓的な差買がみられないけれども，前 者は第 1 ，第 2 小曰歯，第 2 大白菊が萠出し永久潾を列 完成之同時に洞下方への発育が進み，歯槽窝彎入が行わ れるが，後者は永久函萠出の12〜13 才頃より洞下方へ の発青分抑制され洞底函牙接近群，洞底雪牙遠距離群の 百分比が年令之共に漸次増加する・洞底骨皮質は正常群 で18〜19才まで除々に【型十五型が増加しほ心゙完成さ

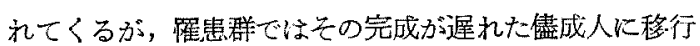
する・このことより副鼻洞䍜患による慢性炎症が永久迷 く列完成期以前に存在士机ば，洞発育抑制の原因となり らると思われる。

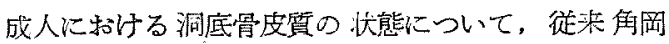
20), 羽田野 32)，三浦が正常者の洞底線快細く，慢性副 鼻洞炎の場合は太くなると報告しているが，著者の観繁 によると，正常群，罹患洋共洞底歯牙遠距雁群に I 型が 1 例もなく， I 型は百分比に僅かの筮しか認められない 点を合せ考察すると，洞底線の太く現れる【型は洞発育

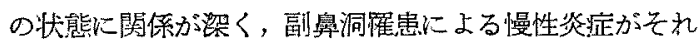

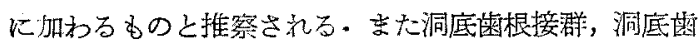
牙接近群で四型を示主毛のか䍜患群に 44 例 (20\%) 存 在することは，上顎断牙がらの影響を一応考虑すべきで ある。

洞底歯根間骨層の距睢的関係俚青年期，壮年其洪年令 的に有意の差が認められないこから，20才頃前後で 上顎洞の発育は一応止まり完成された状態を示するので ある.この点晒頭蓋骨を测定し，上顎洞底と鼻腔底との 位置的関係に対する成人の統計 20)で，洞底が低位にあ るもの約 72\%〜82\%であることは，副鼻洞罹患症例も 含んでいるため，著者の統計よりる低率となつている。

䍜患群に招いて洞底雪牙遠距離群が 40\%を示し，そ の中に $30 \%$ 弱の N 型が 存在することは正常群の $\mathbb{N}$ 型と 統計学的に明らか汇有意の差を認められ，洞発育過程に お汁る副鼻洞罹患に重要な意義があると考兄られ，更に 顏面骨壁の病理組織学的检索を試みた。

この洞底崡根間骨層の肥厚例に対し手術を行つた所， 洞発育不全が全例に確弪され，顏面レ線像の隆影強く，
骨壁不明瞭な場合，洞発育良否判定の一基準とするこ上 ができた・以上の方法により分類された副奥洞炎症例の 骨病変に炎症性变化は極めて少数例であり，Umbauk 關する骨新生，骨吸收が中等度にみられたもの約 25\% で，仁保 ${ }^{\complement 6)}$ ，稲葉 ${ }^{28)}$ の骨病变が殆んど全(例似観察され ている報告とは非常に暴つている。また阿部 ${ }^{199}$ ，军田9) は glatt Resorption のみを骨病変とする含気化学就を 述べているが，大和田 ${ }^{38)}$ はこの事に関し一考を要する と反駁している・著者の検索する所では洞战膜の炎症高 度で同発育良好な症例に咨症性骨病変及び骨吸收の優位 性が誌められ，線維性の慢性炎症が存在する洞発育不全 例に 骨新生の優位性が強く現れている・この骨組䋨变

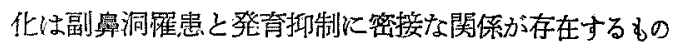
で, 前者の洞発青良好例に対する骨吸収の倛位性怯洞發 去過程に和ける軽度の粘膜炎症方存在している症例飞急 性堌悪が蔆起され細胞浸潤, 浮腫の粘膜所見が骨壁湾 化を生ぜしめる・これに反し後者の場合は学童期即ち承 久雪々列完成前の慢性副鼻洞炎䍜患が洞粘膜に慢性炎症: を和こし，卡の反応として骨壁に Produktiv な变化を 与完たのではなかららか。一方個人の局所体質の素因炕. ついても考雷す心゙きであるら。

\section{第 5 章 結語}

副鼻洞正常者 302 名 (386 側)，漫性副鼻洞炎患者 298 , 名 (457 側)，函性上颚洞炎患者 42 名 (42 側) 飞対し，

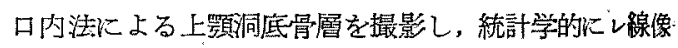
を観察した・更に慢性副鼻洞炎患嘗を洞登育状態よっ て分けた 32 例の顔面骨壁を病理組織学的に検索し，次 の如き成積を得た。

1）正常群の洞底骨皮質は18〜19 頃まで年令と共 に除トに完成されるが，罹患群では完成が迤延する。

2) 洞底歯根間骨層の距離的变化は永久雪々列完成と 同時に洞下方に発青し，洞底と雨根との関係は完成する が，䍜患群は10〜11 才頃より洞底発育が抑制されてく る.

3）成人に括ける洞底蒾根間骨層の状態は青年期々壮 年期の間に統計学的有意差は認められない。

4）副鼻洞罹患と 洞発育不全との閣保仕 30\% 弱化認 められ，正常群との間に有意の差が示された。

5）顔面骨壁の炎症性変化は 4 例 (12.5\%), Umbau による骨変化は 30 例 (93.8\%) に認めら九，洞発育良 好例には骨吸収が多く，不良例には管新生が強く現れる 傾向を示していた。 
文

献

1) Aland, A.: Zbl. Hals. usw. Heilk., 11: 789, 1927. 2) Davis, W.B.: Arch. Otolaryng., 15 : 659, 1932, 3) Maresh, M.M.: Am. J. Dis. Child, $60: 55,1940$, 4) Mensing, G.: Arch. Ohr. usw. Heilk., 146:440, 1939. 5) Sedwick, H.J.: Am. J. Roentgenol., $32: 154,1934 . \quad$ 6) Davis, W.B.: Zbl. Hals. usw. Heilk., 8: 470, 1926.7 7) Stern, K.: Zschr. Hals-usw. Arzt., 30: 301, 1939.8 8) Rosenberger, H.C.: Laryngoscope, 555: 62, 1945. 9) Maresh, M.M. \& Washburn, A.H.: Am. J. Dis. Child., 60:841, 1940. 10) Richter, H.: Z.f. Laryng., 22:102, 1931, 11) Uffenorde: Z.f. Ohr. 72 133: 192, 1915. 12) Albrecht: Zeits. H.N.O. Bd. 10: $1925 . \quad$ 13) Uffenorde: Z.f. Laryng., Bd. 17:1, 1929. 14) Zuckerkandl: Normalen. Pathol. Anatomie der Nasen-hohle u. ihrer Pneumatishen Anhänge. Bd. 1. 15) Manasse: Zeits. f. H.N.O. 4: 473, 1923. 16) Darmochowsky: Arch. f. Larng., 3 : 1995. 17) Eggston: Histropathology of the ear, nose and throat., 1947. 18）阿部香也：日耳悬，58：621, 沿 $30.19 ＼mathrm{~ 阿 部 ~}$ 香也：日耳萛，58：476，昭30.20）田中憲三：大

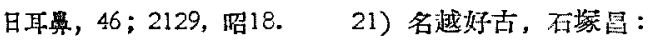

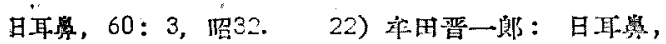

60：376，炤30. 23）倉田寬：日咕㫷，60；413，沼

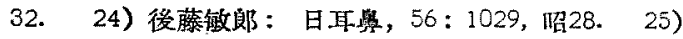
宮島健郎：耳㘈，26：21三，昭29.26）仁保三四㳄，

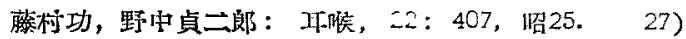

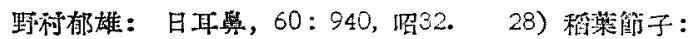

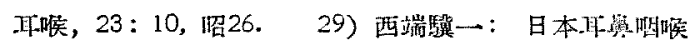

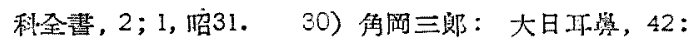
398 , 炤 $11,44 ； 939$, 炤15. 31) 估保田実：䨑利学

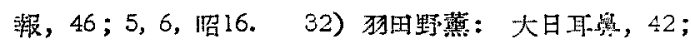
1695, 略 11,$43 ; 110$, 畹12.33) 阿西一秀：日本口

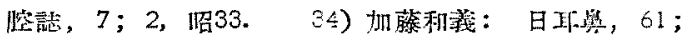
1841 , 昭33. 35) 吉时利一：日而点, 60; 582, 掘32. 36）堀口电作，三浦真一：打搌， $25 ； 459$ ，炤28.

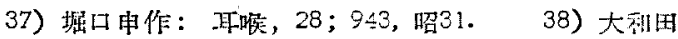

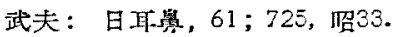

稿を終るに臨み，終始御愁篤なる御指首，御 “校闑を賜わつた恩師堀口电作教授に二深继なる謝

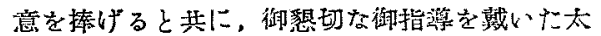

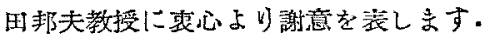

（本論文の要旨は第60回日本功悬咽喉科学全 綛会において発装した.)

（原稿到着=炤和 34.5 .25 日一急載） 